\title{
IDŐJÁRÁS
}

Quarterly Journal of the Hungarian Meteorological Service

Vol. 123, No. 1, January-March, 2019, pp. 57-72

\section{Thermal conditions in the summer season on the Polish coast of the Baltic Sea in 1966-2015}

\author{
Arkadiusz M. Tomczyk ${ }^{1 *}$, Sebastian Kendzierski ${ }^{1}$, Magdalena Kugiejko ${ }^{2}$, \\ and Natalia Pilguj ${ }^{3}$
}

${ }^{1}$ Department of Climatology, Adam Mickiewicz University in Poznań, B. Krygowskiego 10, 61-680 Poznań, Poland

${ }^{2}$ Department of Tourism and Recreation, Adam Mickiewicz University in Poznań, B. Krygowskiego 10, 61-680 Poznań, Poland

${ }^{3}$ Department of Climatology and Atmosphere Protection, University of Wroclaw, A. Kosiby 8, 51-621 Wroctaw, Poland

*Corresponding authorE-mail: atomczyk@amu.edu.pl

(Manuscript received in final form: April 3, 2018)

\begin{abstract}
The Baltic Sea coast is characterized by a large frequency of days with biometeorologically adverse effects. In many Polish and foreign studies there are issues related to the increase in the frequency of warm days, hot days, and heat waves. The present study introduces the characteristics of thermal conditions on the Polish coast in the 19662015 multiyear period, as well as the identification of circulation conditions favoring the occurrence of extremely warm periods. The analysis included the maximum temperature data (obtained from five measurement stations), on the basis of which the characteristics such as: average maximum air temperature, sum of maximum air temperatures occurring in summer, warm days $\left(T_{\max }>25^{\circ} \mathrm{C}\right)$, hot days and heat waves $\left(T_{\max }>30^{\circ} \mathrm{C}\right)$ were determined. The existing thermal classification proposed by Lorenc (2000) was also used in relation to the maximum daily temperature. In addition, there appeared a topic of atmospheric circulation regarding the determination of conditions for the occurrence of exceptionally warm months (mean $T_{\max }>T_{s}+1.5 \sigma$ ). The research results indicate an increase in the average maximum temperature $\left(T_{\max }\right)$ in the summer season in 1966-2015. The changes are particularly visible in the western part of the research area $\left(0.43{ }^{\circ} \mathrm{C} / 10\right.$ years $)$. Furthermore, the observed warming was translated into a higher occurrence of warm and hot days, which was discussed by other authors in the context of the whole of Poland. The occurrence of exceptionally warm months has reached the maximum frequency in the last 15 years, which is associated with positive anomalies of the sea level pressure and the $500 \mathrm{hPa}$ isobaric surface. Periods of occurrence of the above mentioned anomalies were related to the presence of high pressure systems and the advection of air masses from the eastern sector (according to the presented T850 maps).
\end{abstract}

Key-words: air temperature, atmospheric circulation, summer season, climate change, Baltic Sea 


\section{Introduction}

According to the bioclimatic regionalization of Poland, the Baltic Sea coast is classified as a coastal region and is considered the strongest stimulus (KozłowskaSzczęsna et al., 1997). The coastal bioclimate stands out from other climates due to the predominance of climatic stimuli associated with the greater impact of the cooling air value due to the combined effect of low temperature, higher wind speed and air humidity (Kolendowicz et al., 2018). In this region, about $40 \%$ of days a year are considered burdensome in terms of biometeorological conditions (Kozłowska-Szczęsna et al., 2002).

The climate change observed today, manifesting itself, among others, through the increase in air temperature $(I P C C, 2013)$ is of particular importance in regions that are heavily used for tourism. In Poland, the seasonality of tourist traffic is conditioned mainly by the climate and weather changes during the year (Stasiak, 2011; Koźmiński and Michalska, 2016a). According to Krzyżewska (2010), extreme weather phenomena cause not only a decrease in profits from tourism, but also pose a threat to human life and health. This has been particularly important in the last decades, in which an increase in the frequency of hot days and heat waves is observed (Sulikowska et al., 2016; Tomczyk and Bendorz, 2016; Tomczyk and Sulikowska, 2017), which results in a significant increase in the number of deaths caused by biometeorological conditions affecting human body systems (Kuchcik, 2001; Paldy and Bobvos, 2009; Bobvos et al., 2015; Revich et al., 2015). The progressive climate warming will also have a positive impact by extending the summer tourist season mitigating the seasonality phenomenon and, consequently, also the environmental nuisance (Koźmiński and Michalska, 2016a).

Tourism plays a special role in the socio-economic development of coastal towns, where services related to the organization and operation of tourism are the main sources of income (Jażewicz and Rydz, 2001; Matczak and Rydz, 2001; Schwichtenberg, 2006; Jażewicz, 2011; Parzych, 2011). Taking into account the Schneider's index (Warszyńska, 1985; Szromek, 2012), it follows that for 2016, its highest values were reached by voivodships located in the northern part of the country (Central Statistical Office Report, 2017). Comparing the data from 2004 and 2014, the sustainable development of the tourist function was confirmed in the following voivodeships: the Pomeranian, West Pomeranian, and WarmianMasurian (Koźmiński and Michalska, 2016b).

Bearing in mind the increase in the intensity of tourist traffic in northern Poland, it is reasonable to analyze the thermal conditions and their changes. In connection with the above, the following objectives were adopted:

1) characteristics of thermal conditions on the Polish coast of the Baltic Sea in 1966-2015;

2) characteristics of circulation conditions for the occurrence of exceptionally warm months in 1966-2015. 


\section{Data and methods}

The article uses the daily values of maximum air temperature $\left(T_{\max }\right)$ from 1966 to 2015 for five stations located on the Polish coast of the Baltic Sea (Fig. 1). The data was obtained from the resources of the Institute of Meteorology and Water Management - National Research Institute.

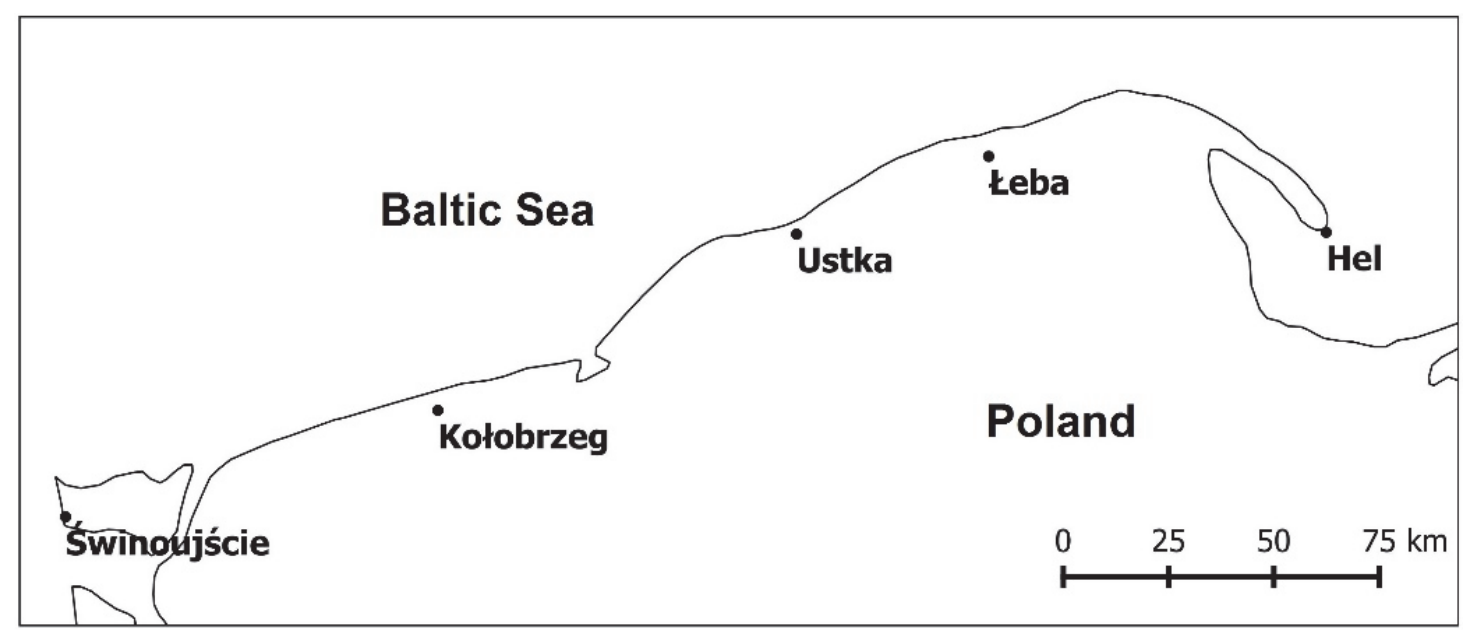

Fig. 1. Locations of the meteorological stations.

Based on the collected data, the basic characteristics were calculated, i.e., the average maximum air temperature in the summer seasons (June-August), as well as the warm $\left(T_{\max }>25^{\circ} \mathrm{C}\right)$ and hot days $\left(T_{\max }>30{ }^{\circ} \mathrm{C}\right)$ and heat waves were determined. Heat wave was defined as a sequence of at least 3 hot days. In addition, a thermal classification proposed by Lorenc (1994) was carried out for months and seasons.

The Lorenc classification is determined by classical measures based on a standardized deviation from the average air temperature. The original Lorenc classification (1994) was based on a 9-class assessment of the average annual air temperature. Then it was extended to 11 classes (Lorenc and Suwalska-Bogucka, 1996; Lorenc, 2000) and applied to assessment of thermal conditions shorter than one year. The assumptions of this method were used in the classification of average values of monthly, annual, and seasonal air temperatures used in the Institute of Meteorology and Water Management - National Research Institute. Despite the existence of other methods for determining thermal classification and the fact that this method has advantages and disadvantages (Czernecki and Miętus, 2011), it was used for the purposes of this article because it is applicable when determining the results for the average maximum air temperature. For the period 1966-2015, individual thermal periods were defined, with distinction between 
monthly and seasonal values, for the reference period 1971-2000. Detailed criteria for determining periods and their names are presented in Table 1.

Table 1. Thermal classification of months, seasons and years according to Lorenc (2000)

\begin{tabular}{cclc}
\hline \hline Color & $\begin{array}{c}\text { Class } \\
\text { number }\end{array}$ & \multicolumn{1}{c}{ Name of the period } & $\begin{array}{c}\text { Threshold values } \\
\text { for air temperature }\end{array}$ \\
\hline \hline 1 & extremely warm & $T_{y}>T_{\text {avg }}+2.5 \sigma$ \\
2 & anomaly warm & $T_{\text {avg }}+2.0 \sigma<T_{y} \leq T_{\text {avg }}+2.5 \sigma$ \\
3 & very warm & $T_{\text {avg }}+1.5 \sigma<T_{y} \leq T_{\text {avg }}+2.0 \sigma$ \\
4 & warm & $T_{\text {avg }}+1.0 \sigma<T_{y} \leq T_{\text {avg }}+1.5 \sigma$ \\
5 & slightly warm & $T_{\text {avg }}+0.5 \sigma<T_{y} \leq T_{\text {avg }}+1.0 \sigma$ \\
6 & normal & $T_{\text {avg }}+0.5 \sigma \leq T_{y} \leq T_{\text {avg }}+0.5 \sigma$ \\
7 & slightly cool (slightly frosty) & $T_{\text {avg }}-1.0 \sigma \leq T_{y}<T_{\text {avg }}-0.5 \sigma$ \\
8 & cool (frosty) & $T_{\text {avg }}-1.5 \sigma \leq T_{y}<T_{\text {avg }}-1.0 \sigma$ \\
9 & very cool (frosty) & $T_{\text {avg }}-2.0 \sigma \leq T_{y}<T_{\text {avg }}-1.5 \sigma$ \\
10 & anomaly cold (cold) & $T_{\text {avg }}-2.5 \sigma \leq T_{y}<T_{\text {avg }}-2.0 \sigma$ \\
11 & extremely cold (frosty) & $T_{y}<T_{\text {avg }}-2.5 \sigma$ \\
\hline
\end{tabular}

where $T_{y}$ is the average annual air temperature, $T_{\text {avg }}$ is the average air temperature in the multiyear period 1971-2000, and $\sigma$ is the standard deviation.

In addition, the circulation conditions for the occurrence of exceptionally warm months, i.e., months with an average $T_{\max }>T_{s}+1.5 \sigma$, were analyzed. According to the Lorenc thermal classification, exceptionally warm months included very warm, anomalously warm, and extremely warm months. In order to determine the pressure conditions, the daily values of atmospheric pressure at sea level $(S L P)$, the height of the $500 \mathrm{hPa}$ isobaric surface $(z 500 \mathrm{hPa})$ and the air temperature at the $850 \mathrm{hPa}$ isobaric surface (T850) were used. Data was obtained from the National Center for Environmental Prediction/National Center for Atmospheric Research (NCEP/NCAR) reanalysis (Kalnay et al., 1996), which are available in the archives of the NOAA ESRL PSD (Earth System Research Laboratory Physical Science Division). On the basis of the aforementioned data, there were averaged maps drawn up for the sea level pressure, together with maps of height of $500 \mathrm{hPa}$ isobaric surface and temperature at the $850 \mathrm{hPa}$ isobaric surface, as well as maps of anomalies. Anomalies were calculated as the difference between average values of individual parameters of selected months and average values for those months from the entire multiyear period. In addition, the Großwetterlage circulation calendar was used to characterize the atmospheric circulation. 


\section{Results}

\subsection{Average $T_{\max }$ in summer}

The average maximum air temperature in the summer season on the Polish coast of the Baltic Sea in the years 1966-2015 ranged from $20.1^{\circ} \mathrm{C}$ in Leba and Ustka to 21.1 in Świnoujście. The lowest average summer $T_{\max }$ ranged from $18.0^{\circ} \mathrm{C}$ in Łeba to $19.2^{\circ} \mathrm{C}$ in Świnoujście. The coldest seasons were primarily in the first half of the analyzed multiyear period and took place in 1974, 1987, and also in 1993 (Fig. 2). In turn, the highest average $T_{\max }$ ranged from $22.2^{\circ} \mathrm{C}$ in Łeba, Ustka and Kołobrzeg, to $23.6^{\circ} \mathrm{C}$ in Świnoujście. The warmest seasons were in 1992 , 2002 and 2006. The course of the average $T_{\max }$ in the analyzed years showed its considerable year-to year fluctuations. In the prevailing area, the variability of the mean $T_{\max }$ was similar, as evidenced by the low variation in the standard deviation values falling within the range of $0.9-1.0$. The analyses showed a statistically significant increase in $T_{\max }$, ranging from $0.20^{\circ} \mathrm{C} / 10$ years (Hel) to $0.43{ }^{\circ} \mathrm{C} / 10$ years (Świnoujście). $T_{\max }$ changes in the first decade of the $21 \mathrm{st}$ century had a significant impact on the increase, when $T_{\max }$ generally exceeded the standard from the years 1966-2015.

In June, the average $T_{\max }$ ranged from $18.2{ }^{\circ} \mathrm{C}$ in Ustka to $19.5^{\circ} \mathrm{C}$ in Świnoujście. In all stations an increase in $T_{\max }$ was observed, which was from $0.01{ }^{\circ} \mathrm{C} / 10$ years in Hel to $0.32{ }^{\circ} \mathrm{C} / 10$ years in Świnoujście, and only at this station the changes were statistically significant. In July, the average Tmax changed from $20.9{ }^{\circ} \mathrm{C}$ in Łeba to $21.9^{\circ} \mathrm{C}$ in Świnoujście. In each station there was a statistically significant increase in $T_{\max }$ and it changed from $0.30{ }^{\circ} \mathrm{C} / 10$ years in Hel to $0.52{ }^{\circ} \mathrm{C} / 10$ years in Świnoujście. In turn, in August the average $T_{\max }$ ranged from $21.0^{\circ} \mathrm{C}$ in Łeba to 21.1 in Świnoujście. Apart from Hel, $T_{\max }$ changes were statistically significant, ranging from $0.21{ }^{\circ} \mathrm{C} / 10$ years in $\mathrm{Hel}$ to $0.46{ }^{\circ} \mathrm{C} / 10$ years in Świnoujście. 

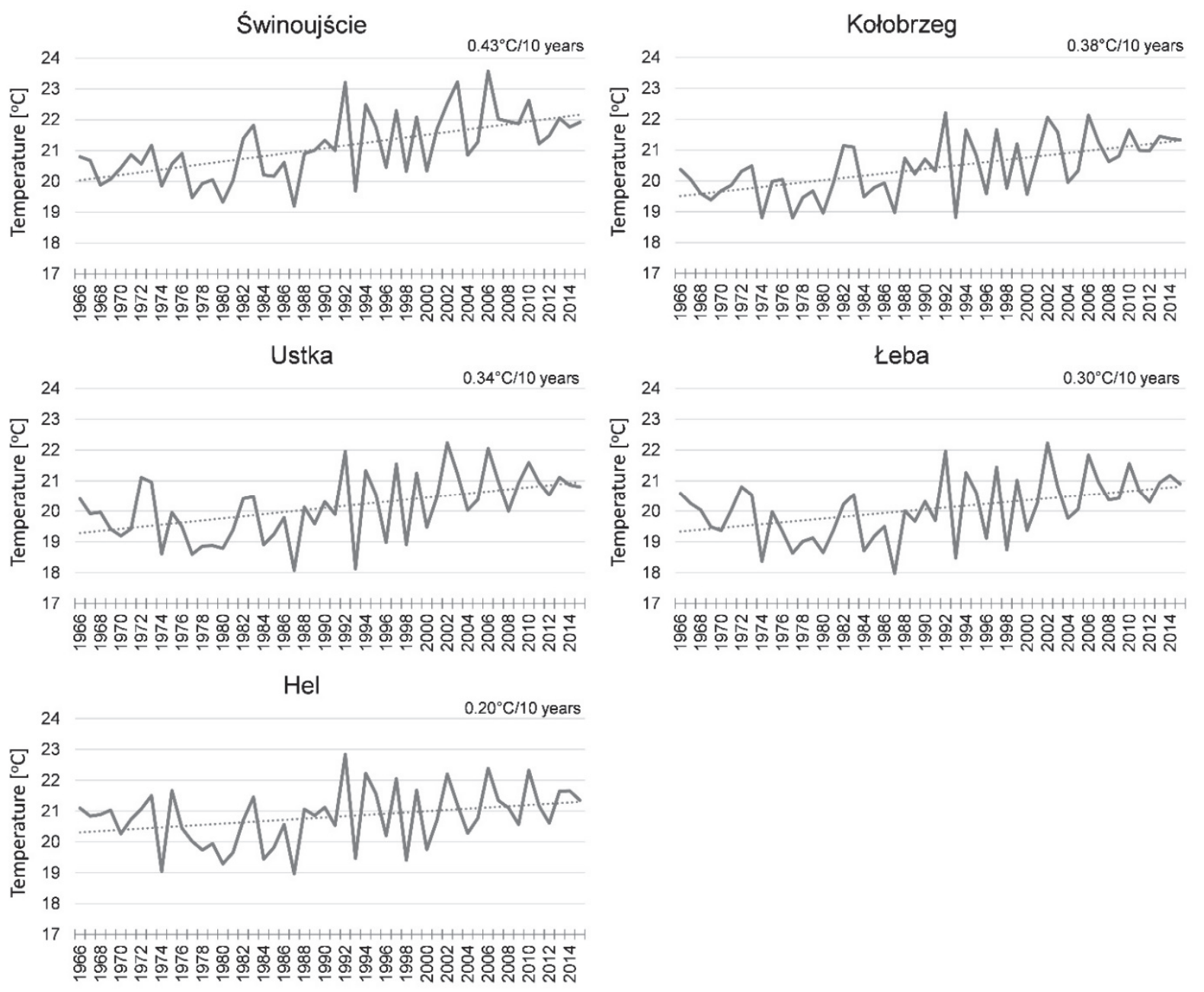

Fig. 2. Mean summer $T_{\max }$ values with trend line.

\subsection{Characteristic days and heat waves}

The total number of warm days $\left(T_{\max }>25^{\circ} \mathrm{C}\right)$ in the analyzed multiyear period fluctuated from 455 in Łeba to 560 in Świnoujście, which gives an average of 9.1 and 11.2 days, respectively, in the season. The smallest number of warm days in the season ranged from 0 in Ustka to 3 in Świnoujście and was recorded mainly in 1977 (Fig. 3). The exception was the station in Hel, where the smallest number was recorded in 2008. In addition, in Świnoujście, the same number of warm days as in 1977 was found in 1968. In turn, the highest number of warm days, apart from the station in Łeba (2002), occurred in 2006. At the individual stations, the highest number of warm days ranged from 20 in Łeba and Kołobrzeg to 29 in Świnoujście. In the analyzed multiyear period, an increase in the number of warm days was observed, which ranged from 0.5 days/10 years in Łeba to 1.2 days/10 years in Świnoujście. Statistically significant changes were recorded in Ustka, Kołobrzeg, and Świnoujście. 
The total number of hot days $\left(T_{\max }>30^{\circ} \mathrm{C}\right)$ changed from 22 in Hel to 113 in Świnoujście. More than 100 days were also recorded in Ustka and Kołobrzeg. At each station, seasons without hot days were recorded and they occurred mainly in the first half of the analyzed multiyear. The maximum number of hot days in the season ranged from 5 in Hel to 9 in Kołobrzeg and Świnoujście. The days of the above category were most frequently recorded in the summer of 1992, 1994 and 2010 (Fig. 3). Hot days were most often recorded in July, and their share fluctuated from $42 \%$ in Świnoujście to $72 \%$ in Hel. In all stations there was an increase in the number of hot days, although statistically significant changes were found only in Świnoujście ( 0.6 days/10 years).

From among the hot days, heat waves were separated into sequences of at least 3 hot days. In the analyzed multiyear period, the smallest number of waves occurred in Hel, only 1, while the largest number was found in Świnoujście -4 waves. The heat wave that occurred at the same time at all stations was the wave of the first half of July 2010. The longest wave occurred in Świnoujście and lasted 5 days, from July 9 to 13, 2010.
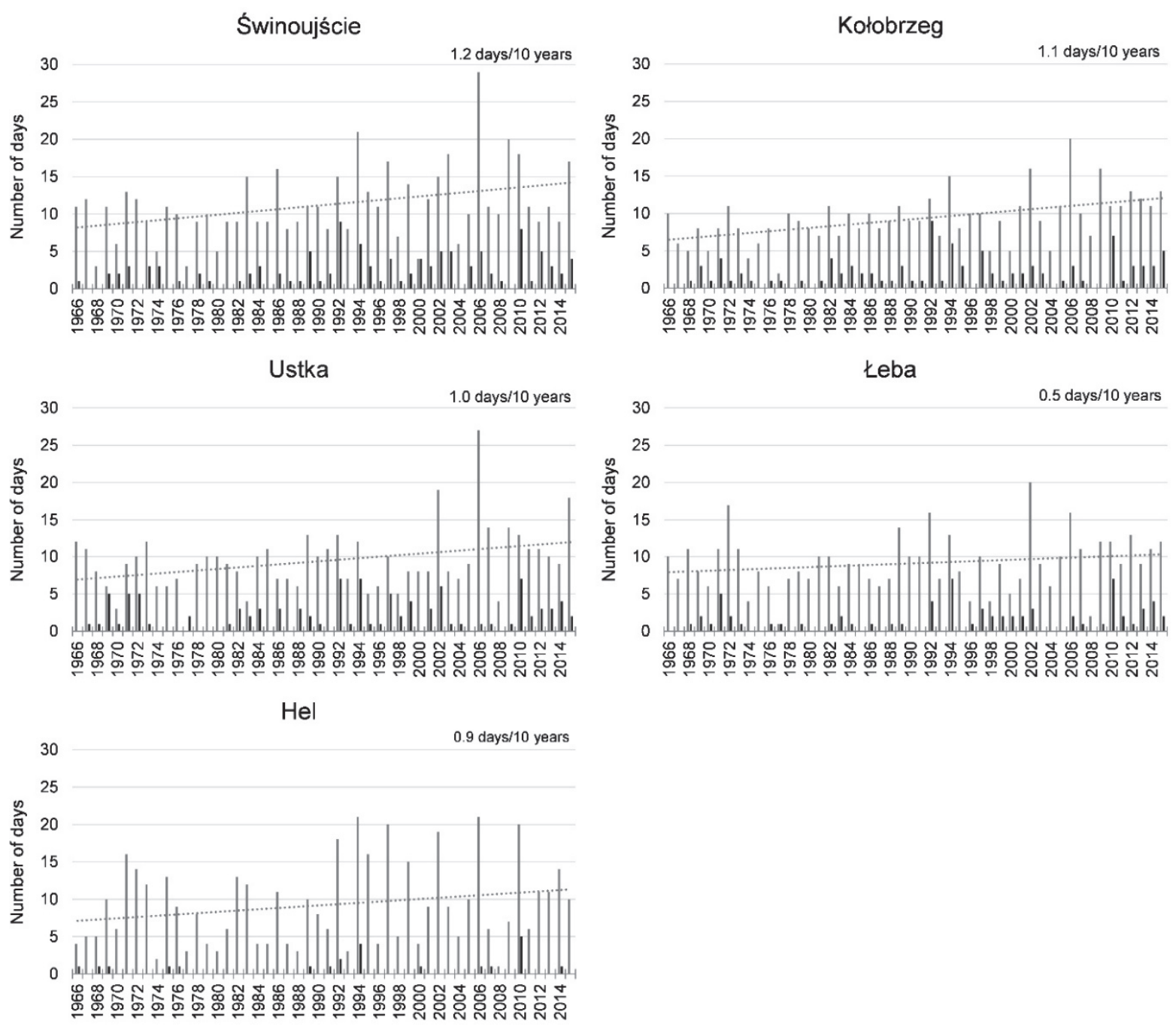

- Warm days - Hot days

Fig. 3. Multiyear series of the annual number of warm and hot days with the trend line (warm days) 


\subsection{Thermal classification}

For the daily maximum air temperature in 1966-2015, thermal classification of the summer months and the season was made (Table 2). Colder and warmer decades can be clearly distinguished. The period of 1966-1971 was characterized by the occurrence of lower temperatures, especially in the western part of the discussed area. 1974 turned out to be exceptionally cold, when the anomalously cold and extremely cold months occurred. In the years 1977-1981, the occurrence of temperatures below the normal range (cold, very cold) was again noticeable. However, during this period, June was different - at all stations the month was usually described as normal. The next colder period was 1984-1987. Then from the 90s, there were no colder subsequent years observed. The year 1993 was extremely cold, when the summer period was classified as very cold and anomalously cold. The years 1995-2001 were characterized by rapid changes in temperature; there were months both extremely warm (1997) and anomalously cold (1998). The first decade and the middle of the second decade of the 21st century were marked as normal and slightly warm. At that time there were months both extremely warm and anomalously warm (July 2006), anomalously warm and very warm (July 2010) as well as cold and very cold (June 2009). Considering the entire period under consideration, the occurrence of maximum temperatures classified as colder than the standard is noted int he period 1966-1990, and warmer months than the standard occured in the years 1992-2015. There is also a spatial differentiation of the classification distribution in the years 1966-1971 for warmer eastern stations and colder western ones.

Table 2. Thermal classification according to Lorenc (2000)

\begin{tabular}{|c|c|c|c|c|c|c|c|c|c|c|c|c|c|c|c|c|c|c|c|c|}
\hline \multirow{2}{*}{ Year } & \multicolumn{3}{|c|}{ Świnoujście } & \multicolumn{3}{|c|}{ Kolobrzeg } & \multicolumn{3}{c|}{ Ustka } & \multicolumn{3}{c|}{ Leba } & \multicolumn{3}{c|}{ Hel } \\
\cline { 2 - 7 } & VI & VII & VIII & JJA & VI & VII & VIII & JJA & VI & VII & VIII & JJA & VI & VII & VIII & JJA & VI & VII & VIII & JJA \\
\hline 1966 & 4 & 8 & 8 & 7 & 3 & 7 & 8 & 6 & 3 & 7 & 7 & 6 & 2 & 6 & 7 & 6 & 4 & 6 & 7 & 6 \\
\hline 1967 & 8 & 6 & 7 & 7 & 8 & 6 & 7 & 7 & 8 & 6 & 6 & 7 & 7 & 6 & 6 & 6 & 7 & 6 & 6 & 6 \\
\hline 1968 & 6 & 9 & 9 & 9 & 5 & 9 & 8 & 8 & 4 & 8 & 7 & 6 & 4 & 8 & 6 & 6 & 4 & 8 & 6 & 6 \\
\hline 1969 & 10 & 6 & 9 & 8 & 10 & 6 & 9 & 9 & 9 & 6 & 8 & 7 & 9 & 5 & 8 & 7 & 6 & 6 & 6 & 6 \\
\hline 1970 & 6 & 7 & 8 & 8 & 6 & 7 & 8 & 8 & 7 & 7 & 8 & 8 & 7 & 7 & 7 & 7 & 6 & 8 & 7 & 7 \\
\hline 1971 & 9 & 6 & 6 & 7 & 9 & 7 & 6 & 8 & 11 & 7 & 5 & 7 & 9 & 6 & 4 & 6 & 8 & 6 & 5 & 6 \\
\hline 1972 & 7 & 6 & 8 & 7 & 6 & 6 & 7 & 7 & 4 & 5 & 6 & 5 & 5 & 5 & 6 & 6 & 6 & 5 & 7 & 6 \\
\hline 1973 & 6 & 6 & 6 & 6 & 6 & 6 & 6 & 6 & 5 & 6 & 6 & 6 & 6 & 6 & 6 & 6 & 5 & 6 & 6 & 6 \\
\hline 1974 & 10 & 8 & 6 & 9 & 11 & 8 & 6 & 10 & 10 & 8 & 6 & 9 & 10 & 9 & 6 & 9 & 10 & 9 & 6 & 10 \\
\hline 1975 & 11 & 6 & 6 & 7 & 10 & 6 & 5 & 7 & 9 & 6 & 5 & 6 & 10 & 6 & 5 & 6 & 7 & 5 & 4 & 5 \\
\hline 1976 & 6 & 6 & 8 & 7 & 6 & 6 & 7 & 7 & 8 & 6 & 7 & 7 & 8 & 6 & 7 & 8 & 7 & 6 & 7 & 7 \\
\hline 1977 & 6 & 9 & 10 & 10 & 6 & 9 & 10 & 10 & 6 & 9 & 9 & 9 & 6 & 9 & 9 & 9 & 5 & 8 & 8 & 8 \\
\hline
\end{tabular}


Table 2. Continue

\begin{tabular}{|c|c|c|c|c|c|c|c|c|c|c|c|c|c|c|c|c|c|c|c|c|}
\hline \multirow{2}{*}{ Year } & \multicolumn{4}{|c|}{ Świnoujście } & \multicolumn{4}{|c|}{ Kołobrzeg } & \multicolumn{4}{|c|}{ Ustka } & \multicolumn{4}{|c|}{ Leba } & \multicolumn{4}{|c|}{ Hel } \\
\hline & \begin{tabular}{|l|} 
VI \\
\end{tabular} & VII & VIII & JJA & VI & VII & VIII & JJA & VI & VII & VIII & JJA & VI & VII & VIII & JJA & VI & VII & VIII & JJA \\
\hline 1978 & 6 & 9 & 8 & 9 & 6 & 9 & 8 & 8 & 7 & 8 & 8 & 9 & 6 & 8 & 8 & 8 & 6 & 8 & 8 & 8 \\
\hline 1979 & 5 & 10 & 7 & 8 & 3 & 10 & 7 & 8 & 4 & 11 & 7 & 8 & 3 & 10 & 8 & 8 & 3 & 10 & 8 & 8 \\
\hline 1980 & 7 & 9 & 9 & 10 & 7 & 8 & 9 & 10 & 6 & 8 & 8 & 9 & 6 & 8 & 8 & 9 & 7 & 9 & 8 & 9 \\
\hline 1981 & 7 & 7 & 9 & 8 & 6 & 7 & 8 & 7 & 6 & 7 & 8 & 8 & 6 & 7 & 8 & 7 & 7 & 8 & 8 & 8 \\
\hline 1982 & 6 & 6 & 6 & 6 & 6 & 6 & 5 & 6 & 6 & 6 & 6 & 6 & 7 & 6 & 6 & 6 & 8 & 6 & 6 & 6 \\
\hline 1983 & 6 & 6 & 6 & 6 & 6 & 6 & 6 & 6 & 6 & 6 & 6 & 6 & 6 & 6 & 6 & 6 & 6 & 5 & 6 & 6 \\
\hline 1984 & 9 & 8 & 6 & 8 & 9 & 8 & 6 & 8 & 10 & 8 & 6 & 8 & 10 & 9 & 6 & 9 & 10 & 8 & 6 & 9 \\
\hline 1985 & 10 & 6 & 7 & 8 & 9 & 6 & 6 & 8 & 8 & 7 & 7 & 8 & 9 & 6 & 7 & 8 & 9 & 7 & 7 & 8 \\
\hline 1986 & 8 & 6 & 8 & 7 & 8 & 6 & 7 & 7 & 6 & 6 & 7 & 7 & 7 & 6 & 7 & 7 & 6 & 6 & 7 & 7 \\
\hline 1987 & 8 & 8 & 10 & 10 & 8 & 7 & 9 & 10 & 8 & 8 & 9 & 10 & 8 & 9 & 9 & 10 & 8 & 8 & 10 & 10 \\
\hline 1988 & 7 & 6 & 7 & 7 & 7 & 5 & 6 & 6 & 7 & 5 & 7 & 6 & 6 & 6 & 7 & 6 & 6 & 6 & 6 & 6 \\
\hline 1989 & 6 & 6 & 7 & 7 & 6 & 6 & 7 & 7 & 7 & 6 & 7 & 7 & 7 & 6 & 7 & 7 & 6 & 6 & 7 & 6 \\
\hline 1990 & 6 & 7 & 6 & 6 & 5 & 8 & 6 & 6 & 4 & 8 & 6 & 6 & 4 & 8 & 6 & 6 & 5 & 7 & 6 & 6 \\
\hline 1991 & 8 & 6 & 6 & 7 & 7 & 6 & 6 & 7 & 8 & 6 & 6 & 7 & 8 & 6 & 6 & 7 & 9 & 6 & 6 & 7 \\
\hline 1992 & 4 & 4 & 4 & 3 & 4 & 5 & 4 & 3 & 4 & 5 & 4 & 4 & 3 & 5 & 5 & 3 & 2 & 5 & 5 & 3 \\
\hline 1993 & 8 & 8 & 9 & 9 & 8 & 8 & 9 & 10 & 9 & 8 & 9 & 10 & 8 & 8 & 8 & 9 & 7 & 8 & 9 & 9 \\
\hline 1994 & 6 & 4 & 6 & 5 & 6 & 4 & 6 & 5 & 6 & 3 & 6 & 5 & 6 & 3 & 6 & 5 & 7 & 2 & 5 & 4 \\
\hline 1995 & 8 & 5 & 5 & 6 & 8 & 5 & 6 & 6 & 7 & 6 & 6 & 6 & 6 & 6 & 6 & 6 & 6 & 6 & 5 & 5 \\
\hline 1996 & 7 & 8 & 6 & 8 & 7 & 9 & 6 & 8 & 8 & 9 & 6 & 8 & 7 & 9 & 6 & 8 & 6 & 8 & 6 & 7 \\
\hline 1997 & 6 & 7 & 1 & 5 & 5 & 7 & 1 & 5 & 5 & 7 & 2 & 4 & 5 & 6 & 3 & 4 & 6 & 6 & 2 & 4 \\
\hline 1998 & 6 & 8 & 9 & 8 & 5 & 7 & 9 & 8 & 6 & 8 & 9 & 8 & 6 & 8 & 10 & 9 & 6 & 8 & 10 & 9 \\
\hline 1999 & 5 & 5 & 6 & 5 & 5 & 5 & 7 & 6 & 4 & 5 & 6 & 5 & 5 & 5 & 6 & 5 & 5 & 5 & 6 & 5 \\
\hline 2000 & 5 & 10 & 7 & 8 & 4 & 10 & 8 & 8 & 5 & 8 & 7 & 7 & 5 & 9 & 7 & 7 & 6 & 9 & 7 & 8 \\
\hline 2001 & 8 & 5 & 5 & 6 & 9 & 5 & 5 & 6 & 8 & 5 & 6 & 6 & 9 & 5 & 6 & 6 & 9 & 5 & 6 & 6 \\
\hline 2002 & 4 & 6 & 4 & 5 & 4 & 6 & 4 & 4 & 4 & 6 & 3 & 3 & 5 & 5 & 2 & 3 & 6 & 6 & 2 & 4 \\
\hline 2003 & 2 & 5 & 5 & 3 & 4 & 6 & 6 & 5 & 4 & 6 & 6 & 5 & 5 & 6 & 6 & 6 & 5 & 6 & 6 & 6 \\
\hline 2004 & 7 & 7 & 6 & 7 & 7 & 8 & 6 & 7 & 7 & 7 & 5 & 6 & 7 & 8 & 5 & 7 & 7 & 8 & 5 & 7 \\
\hline 2005 & 6 & 6 & 8 & 6 & 6 & 6 & 8 & 7 & 6 & 6 & 7 & 6 & 7 & 5 & 7 & 6 & 7 & 5 & 7 & 6 \\
\hline 2006 & 3 & 1 & 6 & 3 & 4 & 2 & 7 & 3 & 4 & 1 & 7 & 4 & 5 & 2 & 6 & 4 & 5 & 2 & 6 & 4 \\
\hline 2007 & 4 & 6 & 6 & 6 & 3 & 6 & 6 & 5 & 4 & 6 & 6 & 6 & 3 & 7 & 6 & 5 & 3 & 7 & 6 & 6 \\
\hline 2008 & 5 & 6 & 6 & 6 & 6 & 6 & 6 & 6 & 6 & 6 & 6 & 6 & 5 & 6 & 6 & 6 & 5 & 6 & 6 & 6 \\
\hline 2009 & 8 & 5 & 4 & 6 & 9 & 5 & 5 & 6 & 8 & 5 & 5 & 6 & 9 & 5 & 5 & 6 & 9 & 6 & 6 & 7 \\
\hline 2010 & 6 & 2 & 6 & 4 & 7 & 3 & 6 & 5 & 6 & 3 & 6 & 4 & 6 & 3 & 5 & 4 & 6 & 3 & 5 & 4 \\
\hline 2011 & 5 & 8 & 6 & 6 & 4 & 7 & 6 & 6 & 4 & 6 & 6 & 6 & 4 & 6 & 6 & 6 & 4 & 6 & 6 & 6 \\
\hline 2012 & 6 & 6 & 6 & 6 & 6 & 6 & 6 & 6 & 6 & 6 & 6 & 6 & 6 & 6 & 6 & 6 & 7 & 6 & 6 & 6 \\
\hline 2013 & 6 & 6 & 5 & 6 & 5 & 6 & 5 & 5 & 5 & 6 & 5 & 5 & 5 & 6 & 6 & 5 & 4 & 6 & 6 & 5 \\
\hline 2014 & 6 & 6 & 6 & 6 & 6 & 4 & 6 & 5 & 6 & 5 & 6 & 6 & 6 & 4 & 6 & 5 & 6 & 4 & 6 & 5 \\
\hline 2015 & 7 & 6 & 4 & 6 & 6 & 6 & 3 & 5 & 7 & 6 & 3 & 6 & 7 & 6 & 3 & 6 & 6 & 6 & 4 & 6 \\
\hline
\end{tabular}




\subsection{Very warm months and their circulation conditions}

In the analyzed multiyear period, the total number of exceptionally warm months ranged from 5 in Świnoujście to 9 in Łeba. Most of these months occurred in the last 15 years. The number of Junes classified as exceptionally warm months ranged from 1 in Ustka to 3 in Hel, Łeba, and Kołobrzeg. Among the months that were classified at more than one station, Junes of 1966, 1979, 1992, and 2007 should be mentioned. In addition, June of 2003 and 2006 were also classified at one station. The situation was different in the case of July, because no exceptionally warm month was found at any stations. At two stations (Kołobrzeg, Świnoujście), two exceptionally warm months were recorded, while there were three warm mounths at the other stations. It was July of 1994, 2006, and 2010. In turn, the number of Augusts classified as exceptionally warm months changed from 1 in Świnoujście to 3 in Łeba and Ustka. These months occurred in 1997, 2002 , and 2015.

The occurrence of exceptionally warm months in June was connected with a ridge of high pressure lying across Europe, within which a local high-pressure area was formed with its centre over the Baltic Sea (>1015 hPa) (Fig. 4). Over Central and Northern Europe, the $S L P$ was higher than the average in June in the analyzed multiyear period, and in the center of the system it was $>2 \mathrm{hPa}$. The $S L P$ anomalies over northern Poland ranged from 0 to $>1.5 \mathrm{hPa}$. Contour lines of isobaric surface $500 \mathrm{hPa}$ over Central Europe bent northward creating its clear elevation, and that indicates the presence of warm air masses on the analyzed days. The majority of the continent was within the range of the $z 500$ positive anomalies. Over the research area, it settled 30-40 m higher. This system generated the advection of warm and continental air masses from the southeast sector. The settling air masses were much warmer than the average in June, as indicated by the positive $T 850$ anomalies, whose center $\left(>2{ }^{\circ} \mathrm{C}\right)$ stretched from southern Poland to the Norwegian Sea. According to the Großwetterlage circulation calendar, the HNFZ (Norwegian Sea/Fennoscandia High), BM (Central European Ridge), and HB (British Isles High) types were recorded much more frequently than the average in the analyzed months. 

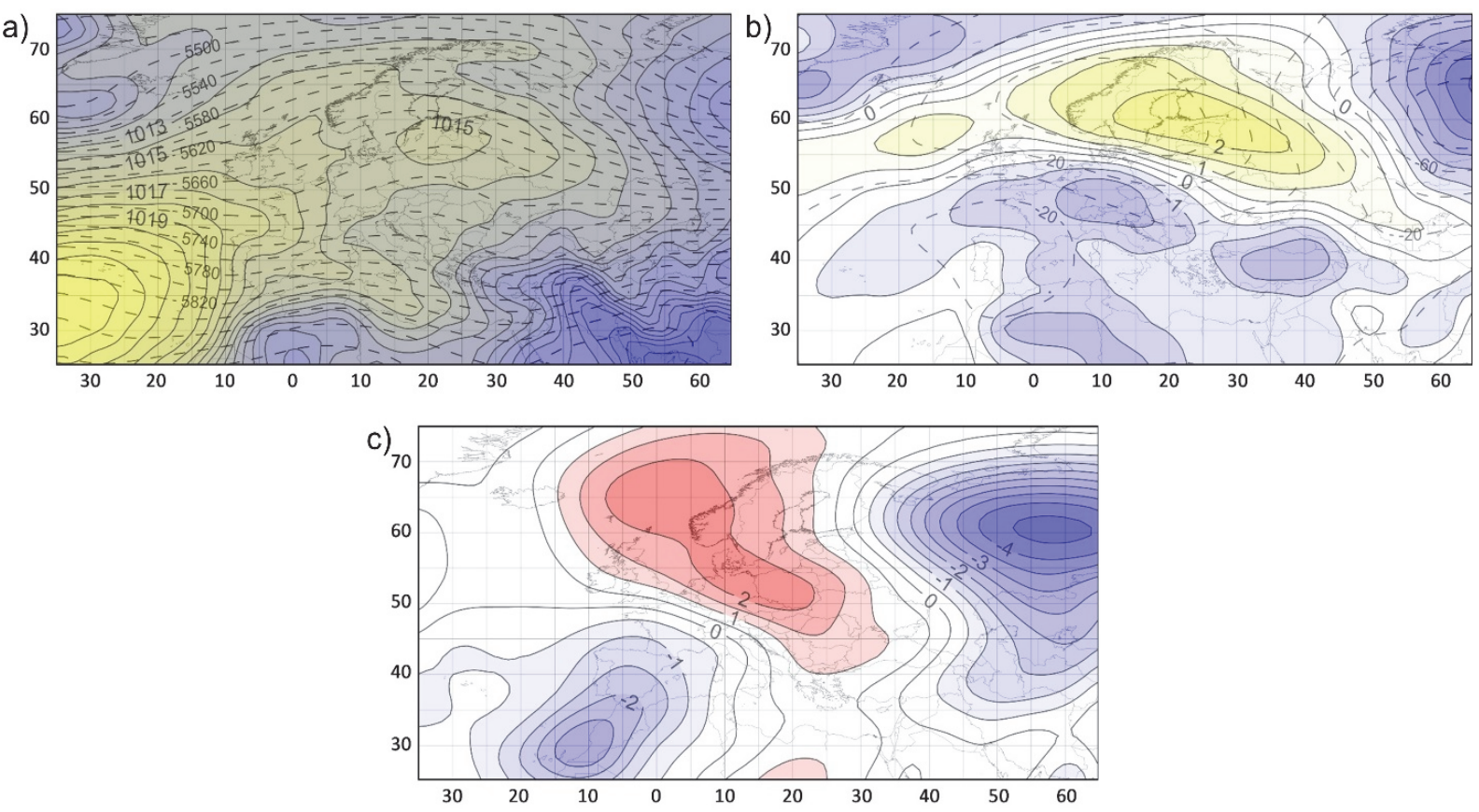

Fig. 4. Mean SLP (color scale) and $z 500$ (dashed line) (a), SLP (color scale) and $z 500$ (dashed line) anomalies (b), and T850 anomalies (color scale) (c) for the exceptionally warm months in June.

Similar pressure conditions caused exceptionally warm months in July. As in the case of June over Europe, there was a high-pressure ridge with a local high pressure area over the Baltic Sea $(>1018 \mathrm{hPa})$ (Fig. 5). At the time the $S L P$ over the major part of the continent was higher than the average in July, maximum $>5$ $\mathrm{hPa}$. Over northern Poland, the anomalies ranged from 3.5 to $4.5 \mathrm{hPa}$. Contour lines of isobaric surface $500 \mathrm{hPa}$ over Central Europe bent north-eastward creating its clear elevation, and that indicates the presence of warm air masses in the analyzed months. Over the research area the $z 500$ values settled higher than the average in July by about $100 \mathrm{~m}$. The described situation provided the inflow of air masses from the south-east, much warmer than the average, as evidenced by the $T 850$ anomalies, which over northern Germany was $>3.5^{\circ} \mathrm{C}$. According to the Großwetterlage circulation calendar, in the analyzed months, BM (Central European Ridge), TRW (Western Europe Trough), and HB (British Isles High) types were observed much more frequently than the average. 

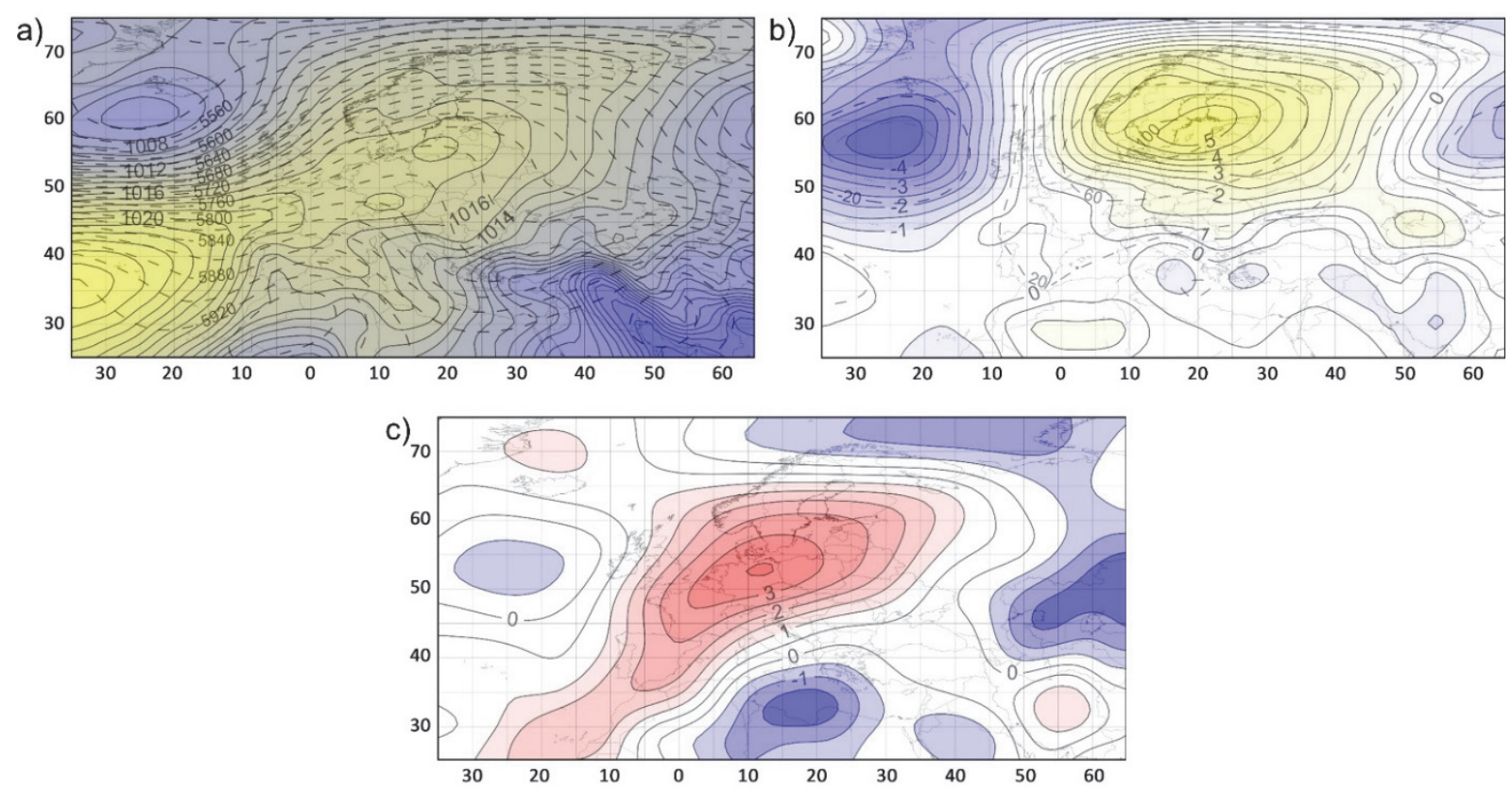

Fig. 5. Mean SLP (color scale) and $z 500$ (dashed line) (a), SLP (color scale) and $z 500$ (dashed line) anomalies (b), and T850anomalies (color scale) (c) for the exceptionally warm months in July.

The occurrence of exceptionally warm months in August was connected with a ridge of high pressure lying across Europe, within which an extensive highpressure area was formed with its centre over Estonia and the Gulf of Finland $(>1019 \mathrm{hPa}$ ) (Fig. 6). In the center of the system, the SLP was higher than the average in August by $>6 \mathrm{hPa}$, and over northern Poland by $1.5-3.5 \mathrm{hPa}$. As in previous months, the contour lines of isobaric surface $500 \mathrm{hPa}$ bent northward. Over the research area, it settled higher than the average by $70-85 \mathrm{~m}$. This system caused the advection of air masses from the eastern and southeastern sectors. Much warmer air masses than the average in August covered the central and northern part of the continent. Over the northern part of Poland, T850 anomalies were approximately $3{ }^{\circ} \mathrm{C}$. According to the Großwetterlage circulation calendar, HFA (Fennoscandian High, anticyclonal), HFZ (Fennoscandian High, cyclonal), SWA (Southwest Circulation, anticyclonal), and TM (Central European Low) types were noted much more frequently in the analyzed months than average. 

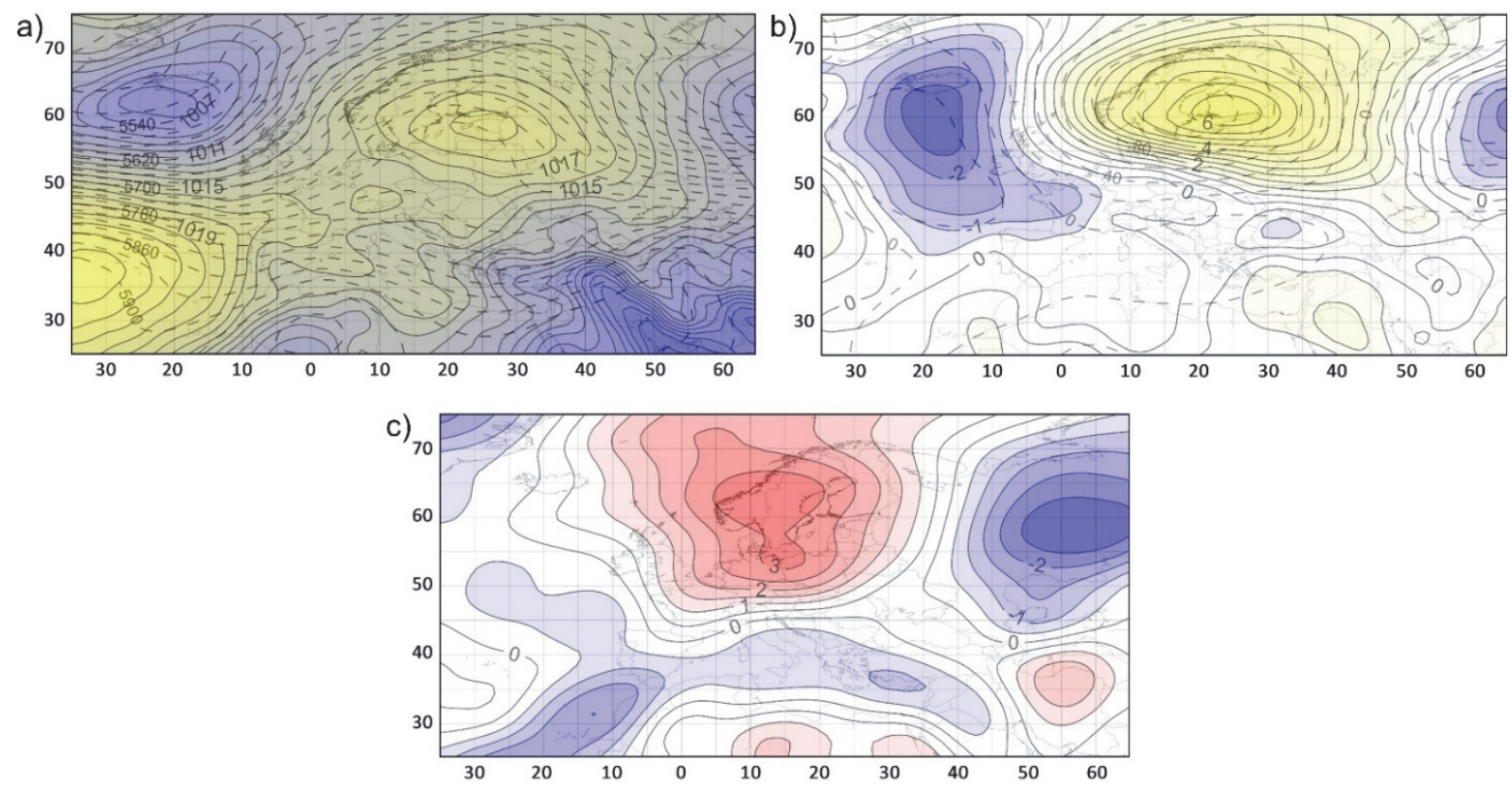

Fig. 6. Mean SLP (color scale) and $z 500$ (dashed line) (a), SLP (color scale) and $z 500$ (dashed line) anomalies (b), and the $T 850$ anomalies (color scale) (c) for the exceptionally warm months in August.

\section{Discussion and summary}

The research confirmed the increase in the mean $T_{\max }$ in the summer season in 1966-2015. The most intense changes were recorded in the western part of the Polish coast of the Baltic Sea and in Świnoujście, and these were $0.43{ }^{\circ} \mathrm{C}$ per 10 years. The previous studies of changes in air temperature, both average annual and average air temperature in particular seasons, have clearly indicated the increase (Tylkowski, 2013; Tomczyk and Bednorz, 2014). The size of these changes is strongly dependent on the adopted multiyear period. Numerous studies also confirm the warming of other Polish regions (Michalska, 2011; Wójcik and Miętus, 2014; Owczarek and Filipiak, 2016). When analyzing the spatial distribution of air temperature increase, it can be shown that the northern and western regions of the country are getting warmer a bit more intensively (Biernacik et al., 2010). A common feature is the most intense warming in spring and summer (Wójcik and Miętus, 2014; Owczarek and Filipiak, 2016).

The observed warming is also translated into an increase in the frequency of warm and hot days. The statistically significant changes in the case of warm days were recorded in Ustka, Kołobrzeg, and Świnoujście, while in the case of hot days only in Świnoujście. Similarly, Tomczyk and Bednorz (2014) found an increase in hot days on the southern coast of the Baltic Sea. These authors adopted a 
definition of characteristic days based on relative thresholds (the basis was the 95th percentile of $T_{\max }$ ), and not on absolute values as in this article, which resulted in showing different rates of change. The increase in the number of warm and hot days has been demonstrated in numerous studies concerning the area of Poland (Ustrnul et al., 2010; Tomczyk, 2014; Owczarek and Filipiak, 2016; Sulikowska et al., 2016; Bartoszek and Krzyżewska, 2017), as well as other European regions (Avotniece et al., 2010; Kundzewicz and Huang, 2010; Kažys et al., 2011; Tomczyk and Bednorz, 2016; Tomczyk and Sulikowska, 2017). The increasing occurrence of warm and hot days has been also translated into the more frequent occurrence of heat waves. The changes taking place have been thoroughly documented by research from Poland (Sulikowska et al., 2016; Bartoszek and Krzyżewska, 2017) as well as Europe (Shevchenko et al., 2014; Tomczyk, 2016; Tomczyk and Bednorz, 2016; Spinoni et al., 2015).

The conducted research also showed more frequent occurrence of exceptionally warm months, most of which occurred in the last 15 years. The more frequent occurrence of months and seasons above the standard is indicated in studies by Twardosz and Kossowska-Cezak (2013). According to these authors, currently observed warming occurs primarily through the increasingly frequent appearance of extremely hot summers, not through the disappearance of extremely cold summers.

The influence of atmospheric circulation on thermal conditions and the occurrence of thermal extremes have been the subject of great interest for many years (Kažys et al., 2011; Unkašević and Tošić, 2015; Tomczyk, 2016). The occurrence of exceptionally warm months was associated with positive anomalies of the sea level pressure and the height of the $500 \mathrm{hPa}$ isobaric surface, which indicates the presence of high pressure systems. During their occurrence, the advection of warm air masses from the eastern sector took place, which was also confirmed on the maps of T850 anomalies. The obtained results are consistent with earlier studies on circulation conditions for the occurrence of days with extreme temperatures, including heat waves in various regions of Central Europe. The occurrence of heat waves on the southern coast of the Baltic Sea was associated with anticyclonal circulation ensuring the advection of warm, continental masses from the southeast and northeast (Tomczyk and Bednorz, 2014). As established by Tomczyk and Bednorz (2016), the occurrence of heat waves in Central Europe was associated with three different types of circulation. In addition to the two types associated with high pressure systems, the occurrence of heat waves was possible during the settling of low pressure center, with its center west of Ireland. Kažys et al. (2011) showed that 1/3 cases of extremely hot weather in Lithuania were related to the advection of air masses from the southeast. A similar direction of inflow of air masses was distinguished for Latvia (Avotniece et al., 2010) and Estonia (Jaagus, 2006).

Acknowledgements: This work was supported by the Polish National Science Centre under grant number: UMO-2014/15/N/ST10/00717. 


\section{References}

Avotniece, Z., Rodinov, V., Lizuma, L., Briede, A. and Kļaviņš, M., 2010: Trends in the frequency of extreme climate events in Latvia. Baltica 23, 135-148.

Bartoszek, K. and Krzyżewska, A., 2017: The atmospheric circulation conditions of the occurrence of heatwaves in Lublin, southeast Poland. Weather 72, 176-180. https://doi.org/10.1002/wea.2975

Biernacik, D., Filipiak, J., Miętus, M. and Wójcik, R., 2010: Zmienność warunków termicznych w Polsce po roku 1951. Rezultaty projektu KLIMAT. In: (Eds.: Bednorz, E., Kolendowicz, L.): Klimat Polski na tle klimatu Europy. Zmiany i ich konsekwencje. Bogucki Wydawnictwo Naukowe, Seria: Studia i Prace z Geografii i Geologii 16. (in Polish)

Bobvos, J., Fazekas, B., and Páldy, A., 2015: Assessment of heat-related mortality in Budapest from 2000 to 2010 by different indicators. Idöjárás 119, 143-158.

Central Statistical Office Report, 2017: Tourism in 2016. Statistical Publishing Establishment, Warsaw.

Czernecki, B. and Miętus, M., 2011: Porównanie stosowanych klasyfikacji termicznych na przykładzie wybranych regionów Polski. Przegląd Geofizyczny 56, 201-233. (in Polish)

IPCC, 2013: Climate change: The physical science basis. Contribution of Working Group I to the Fifth Assessment Report of the Intergovernmental Panel in Climate Change. Cambridge University Press, Cambridge.

Jaagus, J., 2006: Climatic changes in Estonia during the second half of the 20th century in relationship with changes in large-scale atmospheric circulation. Theor. Appl. Climatol. 83,77-88. https://doi.org/10.1007/s00704-005-0161-0

Jażewicz, I. and Rydz, E., 2001: Turystyka jako czynnik rozwoju społeczno-ekonomicznego Łeby. Zeszyty naukowe Wydziału Ekonomii i Zarządzania 8, Koszalin. (in Polish)

Jażewicz, I., 2011: Strategiczna rola turystyki w rozwoju Łeby. In: (Ed.: Jażdżewska, I.): Funkcja turystyczna miast, XXI Konserwatorium Wiedzy w Mieście, Uniwersytet łódzki, Łódź. (in Polish)

Kalnay, E., Kanamistu, M., Kistler, R., Collins, W., Deaven, D., Gandin, L., Iredell, M., Saha, S., White, G., Woollen, J., Zhu, Y., Leetmaa, A., Reynolds, R., Chelliah, M., Ebisuzaki, W., Higgins, W., Janowiak, J., Mo, K.C., Ropelewski, C., Wang, J., Jenne, R., and Joseph, D., 1996: The NMC/NCAR 40-Year Reanalysis Project. Bull. Am. Meteorol. Soc. 77, 437-471. https://doi.org/10.1175/1520-0477(1996)077<0437:TNYRP >2.0.CO;2

Kažys, J., Stankūnavičius, G., Rimkus, E., Bukantis, A., and Valiukas, D., 2011: Long-range alternation of extreme high day and night temperatures in Lithuania. Baltica 24, 71-82.

Kolendowicz, L., Pótrolniczak, M., Szyga-Pluta, K. and Bednorz, E., 2018: Human-biometeorological conditions in the southern Baltic coast based on the universal thermal climate index (UTCI). Theor. Appl. Climatol.134, 363-379. https://doi.org/10.1007/s00704-017-2279-2

Kozłowska-Szczęsna, T., Błażejczyk, K., and Krawczyk, B., 1997: Bioklimatologia człowieka. Metody i ich zastosowanie w badaniach bioklimatu Polski. Monografie, IGiPZ, PAN, 1, Warszawa. (in Polish)

Kozłowska-Szczęsna, T., Błażejczyk, K., Krawczyk, B., and Limanówka, D., 2002: Bioklimat uzdrowisk polskich i możliwości jego wykorzystania w lecznictwie. IGiPZ PAN, Warszawa. (in Polish)

Koźmiński, C. and Michalska, B., 2016a: The seasonal nature of tourist flows in relation to meteorological conditions as illustrated by the case of Zachodniopomorskie Voivodeship. Bulletin of Geography. Socio-economic Series 34, 33-45.

Koźmiński, B. and Michalska, C., 2016b: Sezonowość ruchu turystycznego w Polsce. Zeszyty Naukowe Uniwersytetu Szczecińskiego 3, 9-23. (in Polish)

Krzyżewska, A., 2010: Fale upałów jako zjawisko ograniczające turystykę w dużych miastach świata. Krajobrazy rekreacyjne-kształtowanie, wykorzystanie, transformacja. Problemy Ekologii Krajobrazu 27, 239-244. (in Polish)

Kuchcik, M., 2001: Mortality in Warsaw: is there Any connection with Feather and air pollution? Geographia Polonica 74, 29-45.

Kundzewicz, Z.W. and Huang, S., 2010: Seasonal temperature extremes in Potsdam. Acta Geophysica 58, 1115-1133. https://doi.org/10.2478/s11600-010-0026-5

Lorenc, H., 1994: Ocena zmienności temperatury powietrza i opadów atmosferycznych w okresie 1901-1993 na podstawie obserwacji z wybranych stacji meteorologicznych w Polsce. Wiad. IMGW, 38, 43-59. 
Lorenc, H. and Suwalska-Bogucka, M., 1996: Thermal tendencies of winters in Poland as the indicator of climate variability. Zesz. Nauk. UJ., Prace Geogr. 102, 365-374.

Lorenc, H., 2000: Termiczno-opadowa ocena klimatycznych sezonów roku w Polsce oraz tendencje czasowo-przestrzenne. Projekt badawczy M-9, IMGW, Maszynopis.

Matczak, A. and Rydz, E., 2001: Koncepcja monitoringu ruchu turystycznego w strefie brzegowej Bałtyku (na przykładzie rejonu Ustka-Rowy). Zeszyty Naukowe 1, Wyższa Pomorska Szkoła Turystyki i Hotelarstwa, Bydgoszcz. (in Polish)

Michalska, B., 2011: Tendencje zmian temperatury powietrza w Polsce. Prace i Studia Geograficzne 47, 67-75. (in Polish)

Owczarek, M. and Filipiak, J., 2016: Contemporary changes of thermal conditions in Poland, 19512015. Bulletin of Geography. Physical Geography Series 10.

Paldy, A. and Bobvos, J., 2009: Impact of the Unusual Heatwave of 2007 on Mortality in Hungary. Epidemiology 20, S126-S127. https://doi.org/10.1097/01.ede.0000362437.27958.17

Parzych K., 2011: Wybrane cechy ruchu turystycznego w Kołobrzegu i w świetle wyników pomiaru ruchu turystycznego, Stupskie Prace Geograficzne 8, 75-84. (in Polish)

Revich, B.A., Shaposhnikov, D.A., Podol'naya, M.A., Khor'kova, T.L., and Kvasha, E.A., 2015: Heat Waves in Southern Cities of European Russia as a Risk Factor for Premature Mortality. Studies on Russian Economic Development 26, 142-150. https://doi.org/10.1134/S1075700715020100

Schwichtenberg, A., 2006, Gospodarka turystyczna polskiego wybrzeża, Politechnika Koszalińska, Koszalin. (in Polish)

Shevchenko, O., Lee, H., Snizhko, S., and Mayer, H., 2014: Long-term analysis of heat waves in Ukraine. Int. J. Climatol. 34, 1642-1650. https://doi.org/10.1002/joc.3792

Spinoni, J., Lakatos, M., Szentimrey, T., Bihari, Z., Szalai, S., Vogt, J., and Antofie, T., 2015: Heat and cold waves trends in the Carpathian Region from 1961 to 2010. Int. J. Climatol. 35, 4197-4209. https://doi.org/10.1002/joc.4279

Stasiak, A., 2011: Uwarunkowania i bariery rozwoju turystyki społecznej w Polsce. In: (Eds.: Stasiak A.): Perspektywy i kierunki rozwoju turystyki społecznej w Polsce, Łódź. (in Polish)

Sulikowska, A. Wypych, A. and Woszczek, I., 2016: Fale upałów latem 2015 roku i ich uwarunkowania cyrkulacyjne. Badania Fizjograficzne, Seria A. Geografia Fizyczna (A67), 205-223. (in Polish)

Szromek, A., 2012: Wskaźniki funkcji turystycznej. Koncepcja wskaźnika funkcji turystycznej i uzdrowiskowej, Wydawnictwo Politechniki Śląskiej, Gliwice. (in Polish)

Tomczyk A.M., 2014: Cyrkulacyjne uwarunkowania występowania fal upałów w Poznaniu. Przegląd Geograficzny 86, 41-52. (in Polish) https://doi.org/10.7163/PrzG.2014.1.3

Tomczyk, A.M., 2016: Impact of atmospheric circulation on the occurrence of heat waves in southeastern Europe. Időjárás 120, 395-414.

Tomczyk, A.M. and Bednorz, E., 2014: Heat and cold waves on the southern coast of the Baltic Sea. Baltica 27, 45-54. https://doi.org/10.5200/baltica.2014.27.05

Tomczyk, A.M. and Bednorz, E., 2016: Heat waves in Central Europe and their circulation conditions. Int. J. Climatol. 36, 770-782. https://doi.org/10.1002/joc.4381

Tomczyk, A.M. and Sulikowska, A., 2017: Heat waves in lowland Germany and their circulation-related conditions. Meteorol. Atmos. Phys. 130, 499-515. https://doi.org/10.1007/s00703-017-0549-2

Twardosz, R. and Kossowska-Cezak, U., 2013: Exceptionally hot summers in central and eastern Europe (1951-2010). Theor. Appl. Climatol. 112, 617-628. https://doi.org/10.1007/s00704-012-0757-0

Tylkowski, J., 2013: Temporal and spatial variability of air temperature and precipitation at the Polish coastal zone of the southern Baltic Sea. Baltica 26, 83-94.

Unkašević, M. and Tošić, I., 2015: Seasonal analysis of cold and heat waves in Serbia during the period 1949-2012. Theor. Appl. Climatol. 120, 29-40. https://doi.org/10.1007/s00704-014-1154-7

Ustrnul, Z., Czekierda, D. and Wypych, A., 2010: Extreme values of air temperature in Poland according to different atmospheric circulation classifications. Phys. Chem. Earth 35, 429-436. https://doi.org/10.1016/j.pce.2009.12.012

Warszyńska, J., 1985: Funkcja turystyczna Karpat Polskich. In: Folia Geographica, Series GeographicaOeconomica 18. (in Polish)

Wójcik, R. and Miętus, M., 2014: Niektóre cechy wieloletniej zmienności temperatury powietrza w Polsce (1951-2010). Przeglad Geograficzny 86, 339-364. (in Polish)

https://doi.org/10.7163/PrzG.2014.3.3 